\title{
The correlation between serum E-selectin levels and soluble interleukin-2 receptors with relation to disease activity in localized scleroderma
}

\author{
Karolina Wodok-Wieczorek ${ }^{1}$, Natalia Salwowska², Ewa Syguła ${ }^{1}$, Aleksandra Wodok ${ }^{3}$, Dominika Wcisło-Dziadecka ${ }^{4}$, \\ Katarzyna Bebenek ${ }^{3}$, Beata Bergler-Czop², Ligia Brzezińska-Wcisło²
}

${ }^{1}$ Department of Dermatology, Andrzej Mielęcki Memorial Independent Public Clinical Hospital, Katowice, Poland

${ }^{2}$ Department of Dermatology, School of Medicine in Katowice, Medical University of Silesia, Katowice, Poland

${ }^{3}$ School of Medicine in Katowice, Medical University of Silesia, Katowice, Poland

${ }^{4}$ Department of Cosmetology, School of Pharmacy with Division of Laboratory Medicine in Sosnowiec, Medical University of Silesia, Katowice, Poland

Adv Dermatol Allergol 2018; XXXV (6): 614-619

DOI: https://doi.org/10.5114/ada.2018.77613

\begin{abstract}
Introduction: Scleroderma is a chronic connective tissue disease resulting in fibrosis.

Aim: The aim of the study was to determine the connection between sE-selectin and sIL-2R and the severity of skin lesions in various subtypes of LoS. Evaluation of disease severity, the location of skin lesions, the duration of symptoms and disease activity were assessed in relation to the three different LoS subtypes in patients with localized scleroderma.

Material and methods: The study included 42 patients with localized scleroderma and the control group consisted of 41 healthy subjects. All patients in the LoS study group had a confirmed diagnosis via skin biopsy and underwent serology testing for sE-selectin and SIL-2R concentrations by enzyme-linked immunosorbent assay (ELISA).

Results: Significantly higher levels of sE-selectin and sIL-2R were observed in the LOS study group when compared with the control group $(p<0.001)$. The analysis showed a result close to statistical significance $(p=0.058)$ between sE-selectin concentration during the time of active disease in the LoS study group. The highest concentrations of sE-selectin and SIL-2R were observed in patients with the generalized subtype of LoS. A positive, statistically significant, curvilinear relationship was shown amid the modified Localized Skin Severity Index (mLoSSI) and sE-selectin and SIL-2R concentrations in the LoS study group.

Conclusions: Concentrations of the circulating form of sE-selectin appear to be an adequate marker of the endothelial function, positively correlating with the severity of the disease. The proven correlation of sIL-2R concentrations with the severity of the disease indicates that it is a valuable prognostic factor for predicting the impending course of the disease.
\end{abstract}

Key words: E-selectin, interleukin-2 receptors, localized scleroderma, connective tissue disease.

\section{Introduction}

Scleroderma is a chronic connective tissue disease resulting in fibrosis. The pathogenesis of the disease is not fully understood. Some studies indicate that autoimmune factors lead to vascular wall changes, endothelial injury and inflammatory infiltration which lead to the induction of fibrosis. There are two forms of scleroderma: systemic scleroderma (SSc) and localized scleroderma (morphea, LoS) [1]. Symptoms in LoS are most commonly limited to the dermis, epidermis and subcutaneous tis- sue. There is a high likelihood that microvascular damage is a very important feature of the early stages of localized scleroderma in that it initiates a cascade of processes leading to tissue fibrosis [2]. Vascular abnormalities include an increased expression of adhesion molecules which is noticeable in the area of skin affected by the disease. These molecules strengthen the adhesion of leukocytes and proteins and cause exacerbation of inflammation pending in the vascular wall [3]. One of those proteins is E-selectin whose expression is intensified on the surface of stimulated endothelial cells during the inflam-

Address for correspondence: Dominika Wcisło-Dziadecka MD, PhD, Department of Cosmetology, School of Pharmacy with Division of Laboratory Medicine, Silesian Medical University, 3 Kasztanowa St, 41-200 Sosnowiec, Poland, phone/fax: +48 3225611 82, +48 3225915 80, e-mail: ddziadecka@interia.pl

Received: 9.03.2018, accepted: 2.05.2018. 
matory process. This phenomenon is strongly induced by inflammatory mediators such as interleukin 1 (IL-1), tumor necrosis factor $\alpha$ (TNF- $\alpha$ ) or interferon g (INF- $\gamma)$. In fact, circulating soluble forms of adhesive proteins (abbreviated as 's') are formed as a result of a proteolytic $5^{\text {th }}$ extracellular domain disconnection. They are proponents of adhesion molecule expression and thus can act as indicators of inflammation and vascular abnormalities. At the same time, they stimulate T-cell receptors to produce proinflammatory cytokines [3-6].

Interleukin-2 (IL-2) is well known for its function in the promotion and modulation of the inflammatory process. In response to IL-2, increased synthesis of $\alpha$ chain (CD25) expression occurs leading to the development of a specific high-affinity IL-2 receptor. IL-2R $\alpha$ appears only on the surface of activated lymphocytes. Its $45 \mathrm{kDa}$ fragment, called soluble IL-2 receptor (sIL2-R), is released into the blood stream. SIL-2R binds free IL-2 and thereby contributes to the immunomodulating functions of other interleukins as well. It appears to be a very good marker of immune system activity and its increased levels are observed among other autoimmune diseases $[1,7,8]$.

\section{Aim}

The aim of the study was to determine the connection between sE-selectin and SIL-2R and the severity of skin lesions in various forms of localized scleroderma (LoS). The evaluation of severity and damage, the location of skin changes, the duration of active disease and disease activity was assessed in relation to the three different LoS subtypes in the LoS study group.

\section{Material and methods}

The LoS study group included 42 patients with localized scleroderma which consisted of 35 women and 7 men aged 21 to 65 years (mean age: $49.0 \pm 14.4$ ). The control group consisted of 41 healthy subjects including 28 women and 13 men aged 23 to 65 years (mean age: $46.3 \pm 12.6$ ). The LoS study group and control group were statistically homogeneous in terms of age $(p=0.171)$ and $\operatorname{sex}(p=0.109)$.

All patients in the LoS study group met the inclusion criteria which includes the characteristic clinical presentation of LoS which were confirmed by skin biopsy. Exclusion criteria were: comorbidities, infection, immunosuppressive therapy and systemic steroid therapy within 3 months prior to the study. Despite being known as a 'localized' disease, one quarter of LoS patients have a comorbidity, including orthopedic, neurologic, ocular, and other autoimmune conditions [9, 10]. All participants received detailed information on the purpose of the study and its methodology. Informed consent was obtained. The study was performed according to the protocol which received positive opinion from the Bioethics
Committee of the Medical University of Silesia (resolution No. KNW/0022/KB1/150/12 form 27.11.2012).

The subtype of the disease was evaluated in all patients in the LoS study group. These include the generalized subtype, the plaque subtype and the linear subtype. The Localized Scleroderma Assessment Tool (LoSCAT) is easy to use and includes two LoS domains: the modified Localized Skin Severity Index (mLoSSI), which measures disease activity, and the Localized Scleroderma Damage Index (LoSDI), which measures damage. Both were found to have excellent reliability and validity in prior LoS studies [11-13]. All patients were evaluated through assessing the location of the skin lesions. This was done by measuring the duration of the disease which was done by counting time lapsed from the onset of the initial symptom or a reactivation of the existing lesions and by measuring disease activity based on the mLoSSI [12]. All patients in the LoS study group underwent serology testing for concentrations of serum sE-selectin and SIL-2R levels by the enzyme-linked immunosorbent assay (ELISA).

\section{Statistical analysis}

Statistica (version 10) and IBM SPSS (version 22) were used for statistical computation.

\section{Results}

The findings showed that significantly higher levels of sE-selectin were observed in the study group with LoS when compared with the control group $(p<0.001)$. In patients' serum, the concentration of $\mathrm{sE}$-selectin was in the range of $17.45-99.50 \mathrm{ng} / \mathrm{ml}$ (median: $34.75 \mathrm{ng} / \mathrm{ml}$ ), whereas in the control group, the concentration of $\mathrm{sE}$ selectin ranged from 10.00 to $74.45 \mathrm{ng} / \mathrm{ml}$ (median: 21.40 ng/ml) (Table 1).

Analysis of SIL-2R concentrations showed statistically significant differences between the LoS study group and the control group. The patients with LoS sIL-2R concentrations ranged from 2.98 to $20.08 \mathrm{ng} / \mathrm{ml}$ (median: 8.99 $\mathrm{ng} / \mathrm{ml}$ ) and were significantly higher in comparison to the control group $(p<0.001)$. The control group SIL-2R concentrations ranged from 2.74 to $13.80 \mathrm{ng} / \mathrm{ml}$ (median: $6.22 \mathrm{ng} / \mathrm{ml}$ ) (Table 1).

Out of the 42 patients in the LoS study group, 3 subtypes were indentified based on the characteristics of the disease. Nineteen of the patients were diagnosed with the generalized subtype, 14 were diagnosed with the plaque subtype while 9 patients were diagnosed with the linear subtype.

The highest concentrations of sE-selectin, ranging from 21.40 to $99.50 \mathrm{ng} / \mathrm{ml}$ (median: $54.85 \mathrm{ng} / \mathrm{ml}$ ), were observed in patients with the generalized scleroderma subtype. Results obtained from the patients with the generalized subtype were statistically significant and were higher when compared with the patients who 
Table 1. Comparison of concentrations of investigated molecules in the study and the control group

\begin{tabular}{|c|c|c|c|c|c|c|c|c|c|c|}
\hline $\begin{array}{l}\text { Investigated } \\
\text { molecules }\end{array}$ & Group & $\begin{array}{c}\text { Number } \\
\text { of people }\end{array}$ & Average & $\begin{array}{l}\text { Standard } \\
\text { deviation }\end{array}$ & $\begin{array}{l}\text { Basis } \\
\text { of error }\end{array}$ & $\begin{array}{c}\text { Lower } \\
\text { quartiles }\end{array}$ & Median & $\begin{array}{c}\text { Upper } \\
\text { quartiles }\end{array}$ & Range & $\begin{array}{c}\text { Statistical } \\
\text { search }\end{array}$ \\
\hline \multirow{3}{*}{$\begin{array}{l}\text { sE-selectin } \\
{[\mathrm{ng} / \mathrm{ml}]}\end{array}$} & Study & 42 & 43.62 & 21.66 & 3.34 & 26.30 & 34.75 & 54.85 & $17.45-99.50$ & \multirow{3}{*}{$\begin{array}{l}Z=4.67 \\
p<0.001\end{array}$} \\
\hline & Control & 41 & 25.30 & 12.92 & 2.02 & 18.95 & 21.40 & 29.10 & $10.00-74.45$ & \\
\hline & All & 83 & 34.57 & 20.03 & 2.20 & 21.10 & 27.95 & 42.30 & $10.00-99.50$ & \\
\hline \multirow{3}{*}{$\begin{array}{l}\mathrm{slL}-2 \mathrm{R} \\
{[\mathrm{ng} / \mathrm{ml}]}\end{array}$} & Study & 42 & 9.95 & 3.99 & 0.62 & 7.60 & 8.99 & 11.70 & $2.98-20.08$ & \multirow{3}{*}{$\begin{array}{c}Z=4.5 \\
p<0.001\end{array}$} \\
\hline & Control & 41 & 5.69 & 2.15 & 0.34 & 5.34 & 6.22 & 7.70 & $2.74-13.80$ & \\
\hline & All & 83 & 8.29 & 3.61 & 0.40 & 5.74 & 7.62 & 9.74 & $2.74-20.80$ & \\
\hline
\end{tabular}

had the plaque subtype in which the concentrations of sE-selectin ranged from 17.45 to $63.65 \mathrm{ng} / \mathrm{ml}$ (median: $31.30 \mathrm{ng} / \mathrm{ml})(p=0.18)$. The analysis showed significantly higher concentrations of the measured parameters in the generalized subtype than in the linear subtype ( $p=0.030$ ) where the values ranged from 23.60 to $50.90 \mathrm{ng} / \mathrm{ml}$ (median: $29.20 \mathrm{ng} / \mathrm{ml}$ ). On the other hand, there was no significant difference in sEselectin concentration between the plaque and linear subtypes ( $p=0.983)$.

sE-selectin levels were compared to the control group in all three subtypes of localized scleroderma in the LoS study group, with the values of the following parameters. Statistically significant differences in sE-selectin concentrations were observed in all subtypes of the disease when compared to the control group. Values of the examined parameters in patients with the generalized LoS subtype ranged from 21.40 to $99.50 \mathrm{ng} / \mathrm{ml}$ (median: $54.85 \mathrm{ng} / \mathrm{ml}$ ) and were statistically significant ( $p<0.001$ ). These results were higher than the healthy control group participants where it ranged from 10 to $74.45 \mathrm{ng} / \mathrm{ml}$ (median: $21.4 \mathrm{ng} / \mathrm{ml}$ ).

A similar relationship was also observed in the plaque subtype ( $p=0.017$ ) where sE-selectin levels ranged from 17.45 to $63.65 \mathrm{ng} / \mathrm{ml}$ (median: $31.30 \mathrm{ng} / \mathrm{ml}$ ) and the linear subtype $(p=0.040)$ in which sE-selectin concentrations ranged from 23.60 to $50.90 \mathrm{ng} / \mathrm{ml}$ (median: $29.20 \mathrm{ng} / \mathrm{ml}$ ). The results of the statistical analysis of the relationship between sE-selectin concentrations between the patient group with LoS and the control group of healthy individuals are presented in Table 2.
We assessed the relationship between the subtypes of LoS and SIL-2R serum levels. The highest values of the parameters tested range from 5.1 to $19.72 \mathrm{ng} / \mathrm{ml}$ (median $=9.94 \mathrm{ng} / \mathrm{ml}$ ) and were found among patients with the generalized subtype. Medium concentrations of sIL-2R, ranging from 5.34 to $20.088 \mathrm{ng} / \mathrm{ml}$ (median = $8.23 \mathrm{ng} / \mathrm{ml}$ ) were reported in the plaque subtype, while the lowest was seen in the linear subtype which ranged from 2.98 to $19.24 \mathrm{ng} / \mathrm{ml}$ (median = $7.52 \mathrm{ng} / \mathrm{ml}$ ). The studies did not show any statistically significant relationship between sIL-2R serum concentration and the LoS subtype.

The results of sIL-2R concentrations showed a statistically significant difference $(p<0.001)$ between the group of patients with the generalized subtype, where sIL-2R ranged from 5.10 to $19.72 \mathrm{ng} / \mathrm{ml}$ (median: $9.94 \mathrm{ng} / \mathrm{ml}$, and the control group where it ranged from 2.74 to $13.80 \mathrm{ng} / \mathrm{ml}$ (median: $6.22 \mathrm{ng} / \mathrm{ml}$ ). The patients with the plaque subtype the sIL-2R concentrations ranged from 5.34 to $20.08 \mathrm{ng} / \mathrm{ml}$ (median: $8.23 \mathrm{ng} / \mathrm{ml}$ ) and were statistically significantly higher $(p=0.001)$ when comparing to the control group. There were no significant differences in the SIL-2R concentrations between patients with linear subtype and the control group. The results of statistical analysis of SIL-2R concentrations between LoS subtypes and the control group are presented in Table 3 .

The analysis of the correlation between sE-selectin and SIL-2R concentrations and disease activity based on the mLoSSI scale is presented in Figure 1. A positive, statistically significant, curvilinear, relationship was shown

Table 2. Analysis of SE-selectin concentrations between the study and control groups

\begin{tabular}{|c|c|c|c|c|c|}
\hline Assessed relationship & & Number of people & sE-selectin average range $[\mathrm{ng} / \mathrm{ml}]$ & $Z$ & $P$-value \\
\hline \multirow{2}{*}{$\begin{array}{l}\text { Generalized type } \\
\text { vs. control group }\end{array}$} & Generalized type & 19 & 46.7 & \multirow[t]{2}{*}{4.89} & \multirow[t]{2}{*}{$<0.001$} \\
\hline & Control group & 41 & 23.0 & & \\
\hline \multirow{2}{*}{$\begin{array}{l}\text { Plaque type vs. control } \\
\text { group }\end{array}$} & Plaque type & 14 & 36.8 & \multirow[t]{2}{*}{2.38} & \multirow[t]{2}{*}{0.017} \\
\hline & Control group & 41 & 25.0 & & \\
\hline \multirow{2}{*}{$\begin{array}{l}\text { Linear type vs. control } \\
\text { group }\end{array}$} & Linear type & 9 & 34.6 & \multirow[t]{2}{*}{2.06} & \multirow[t]{2}{*}{0.040} \\
\hline & Control group & 41 & 23.5 & & \\
\hline
\end{tabular}


Table 3. Analysis of sIL-2R concentrations between the study and control groups

\begin{tabular}{|c|c|c|c|c|c|}
\hline Assessed relationship & & Number of people & slL-2R average range $[\mathrm{ng} / \mathrm{ml}]$ & $z$ & $P$-value \\
\hline \multirow[t]{2}{*}{ Generalized type vs. control group } & Generalized type & 19 & 45.5 & 4.51 & $<0.001$ \\
\hline & Control group & 41 & 23.6 & & \\
\hline \multirow[t]{2}{*}{ Plaque type vs. control group } & Plaque type & 14 & 40.0 & 3.23 & 0.001 \\
\hline & Control group & 41 & 23.9 & & \\
\hline \multirow[t]{2}{*}{ Linear type vs. control group } & Linear type & 9 & 30.3 & 1.07 & 0.283 \\
\hline & Control group & 41 & 24.5 & & \\
\hline
\end{tabular}

between mLoSSI and SE-selectin and SIL-2R concentrations in the LoS study group. In patients with more severe disease, the serum concentrations of the parameters were also increased. sE-selectin presented with a moderate correlation $(p<0.001)$ and sIL-2R presented with a weak correlation $(p=0.003)$.

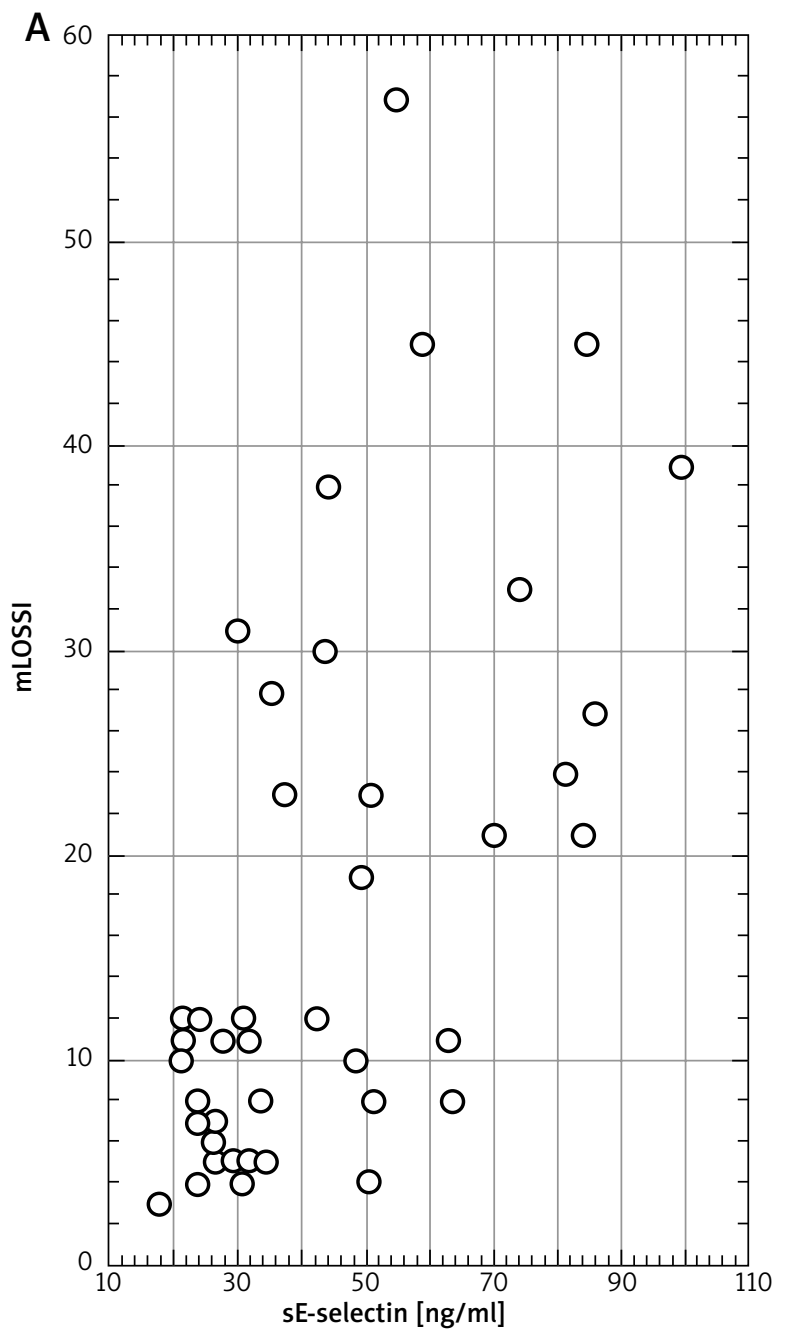

The analysis showed a statistically significant $(p=$ 0.058) correlation between sE-selectin concentration and duration of disease activity in the LoS study group. Higher values of the parameters were observed in patients whose active phase was longer. No similar relationship was observed for sIL-2R concentrations ( $p=0.748)$.

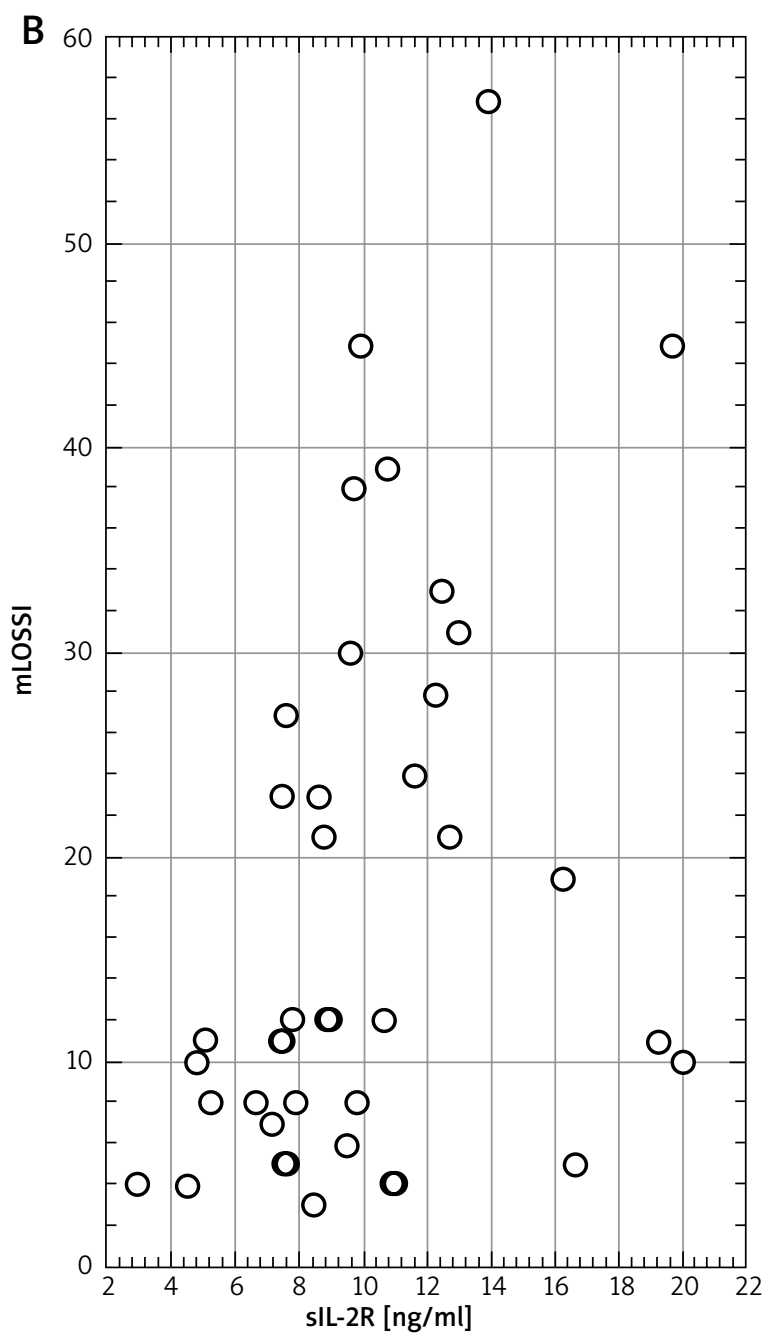

Figure 1. Relationship between sE-selectin (A) and SIL-2R (B) concentrations and disease activity (mLoSSI) in patients with scleroderma 


\section{Discussion}

The early active phase of scleroderma has the most characteristic effect due to the damage caused by the stimulation of endothelial cells and immune system activation resulting in the initiation of the inflammatory process. sE-selectin levels in serum and from the biopsies of skin lesions are an adequate marker of endothelial function which has been confirmed in many studies concerning systemic and localized scleroderma. This correlates with the severity of the disease and the surface area affected by the disease. In cases of systemic sclerosis, organ changes also show this correlation.

Significantly higher levels of sE-selectin have been shown in patients with LoS as compared to the control group ( $p<0.001)$. They directly correlated with the severity of the skin lesions evaluated using the mLoSSI scale $(p<0.001)$ and the highest values were noted in the generalized subtype.

Damage to the vascular endothelium and activation of the inflammatory response which is manifested by increased secretion of E-selectin are the most characteristic early stages of scleroderma. Hypothetically, the highest concentrations of this molecule should be associated with the initial active phase of the disease. Longitudinal studies confirmed this relationship in systemic sclerosis. There is an increase in sE-selectin levels which correlates with the severity of vascular pathology assessed via capillaroscopy which was performed during the first 48 months of SSc. Similar observations were linked to scleroderma where elevated sE-selectin levels were observed in patients with disease duration averaging $2.9 \pm 2.2$ years while those with a history of about $4.9 \pm 5.9$ years had normal sE-selectin concentrations. Our study does not confirm lower concentrations in patients with a longer disease history. This is most likely due to the fact that only patients presenting with active lesions, for an average of approximately 12 months (3 to 24 months), were included in the study [4, 5, 14-21].

The role of increased immune activity manifested by increased synthesis of different stimulation markers is one of the key components of the pathogenesis of scleroderma. Many studies have confirmed elevated levels of sIL-2R in serum and skin lesions in patients with systemic sclerosis. This correlates with disease severity and was higher in patients with diffuse cutaneous systemic sclerosis (dcSSc) than in limited cutaneous systemic sclerosis (IsSSc) and in cases of rapid progression of systemic lesions [22]. Patients undergoing immunosuppressive treatment had decreased concentrations of sIL-2R. Elevated levels of sIL-2R have also been reported in patients with scleroderma $(p<0.001)$ and a positive correlation was noted between SIL-2R concentrations and the surface area of affected skin.

This study confirms a positive, curvilinear relationship between severity of scleroderma and SIL-2R concentrations $(p=0.003)$ and indicates that there is no statis- tically significant difference between the values of this parameter and the different clinical manifestations of LoS. Long-term follow-up of patients with systemic sclerosis shows a reduction in SIL-2R levels during the course of the disease which indicates improvement in clinical status. In our studies there was no correlation between the duration of scleroderma and the concentrations of the tested molecule. However, it should be noted that all analyzed cases involved in the study presented with active forms of the disease. Based on the available studies it can be concluded that, similarly to SSc, localized scleroderma will show improvement in clinical status if accompanied by a decrease in SIL-2R levels which are associated with decreased immune activity $[23,24]$.

\section{Conclusions}

Our study and available resources confirm the significant contribution of E-selectin to the pathogenesis of scleroderma, especially in the initial, active phase of the disease. Concentrations of the circulating form of this adhesion molecule appear to be a sufficient marker of endothelial function, directly correlating with the severity of the disease. The role of SIL-2R as a marker of immune system activity in localized scleroderma has been confirmed in both our research and earlier reports. The proven correlation of sIL-2R concentrations with the severity of the disease seems to make it a valuable prognostic factor for predicting further course of the disease.

\section{Acknowledgments}

The study was performed according to the protocol which received a positive opinion from the Bioethics Committee of the Medical University of Silesia (resolution No. KNW/0022/KB1/150/12 of 27.11.2012).

Research was conducted at Andrzej Mielęcki Silesian Independent Public Hospital, Katowice, Poland, Chair and Department of Dermatology.

\section{Conflict of interest}

The authors declare no conflict of interest.

\section{References}

1. Chung L, Lin J, Furst DE, Fiorentino D. Systemic and localized scleroderma. Clin Dermatol 2006; 24: 374-92.

2. Fett N, Werth VP. Update on morphea: part I. Epidemiology, clinical presentation, and pathogenesis. J Am Acad Dermatol 2011; 64: 217-28.

3. Dunne JV, van Eeden SF, Keen KJ. L-selectin and skin damage in systemic sclerosis. PLoS One 2012; 7: e44814.

4. Iversen LV, Ostergaard O, Ullman S, et al. Circulating microparticles and plasma levels of soluble e- and p-selectins in patients with systemic sclerosis. Scand I Rheumatol 2013; 42: 473-82. 
5. Hasegawa M, Asano Y, Endo H, et al. Serum adhesion molecule levels as prognostic markers in patients with early systemic sclerosis: a multicentre, prospective, observational study. PLoS One 2014; 9: e88150.

6. Tedder TF, Steeber DA, Chen A, Engel P. The selectins: vascular adhesion molecules. FASEB J 1995; 9: 866-73.

7. Church AC. Clinical advances in therapies targeting the interleukin-2 receptor. QJM 2003; 96: 91-102.

8. Lis-Święty A, Brzezińska-Wcisło L, Wcisło-Dziadecka D. Badanie stężenia rozpuszczalnego receptora interleukiny 2 w surowicy chorych na twardzinę układową przed leczeniem i po leczeniu immunosupresyjnym. Dermatol Klin 2006; 8: 165-9.

9. Zulian F, Vallongo C, Woo P, et al. Localized scleroderma in childhood is not just a skin disease. Arthritis Rheum 2005; 52: 2873-81.

10. Saxton-Daniels S, Jacobe HT. An evaluation of long-term outcomes in adults with pediatric-onset morphea. Arch Dermatol 2010; 146: 1044-5.

11. Arkachaisri T, Pino S. Localized scleroderma severity index and global assessments: a pilot study of outcome instruments. J Rheumatol 2008; 35: 650-7.

12. Arkachaisri T, Vilaiyuk S, Li S, et al. The Localized Scleroderma Skin Severity Index and Physician Global Assessment of Disease Activity: a work in progress toward development of localized scleroderma outcome measures. J Rheumatol 2009; 36: 2819-29.

13. Arkachaisri T, Vilaiyuk S, Torok KS, Medsger TA. Development and initial validation of the localized scleroderma skin damage index and physician global assessment of disease damage: a proof-of-concept study. Rheumatology 2010; 49: 373-81.

14. Lis-Święty A, Wcisło-Dziadecka D, Kulawik I. Badanie stężenia e-selektyny w surowicy u chorych z chorobą Raynauda i twardziną układową. Postep Derm Alergol 2005; 22: 250-4.

15. Dziankowska-Bartkowiak B, Żebrowska A, Erkiert-Polguj A, et al. Chosen selectins and integrins in systemic sclerosis skin lesions. Adv Dermatol Allergol 2007; 24: 256-62.

16. Yamane K, Ihn H, Kubo M, et al. Increased serum levels of soluble vascular cell adhesion molecule 1 and E-selectin in patients with localized scleroderma. J Am Acad Dermatol 2000; 42: 64-9.

17. Takehara K, Sato S. Localized scleroderma is an autoimmune disorder. Rheumatology 2005; 44: 274-9.

18. Hasegawa M, Asano Y, Endo H, et al. Serum adhesion molecule levels as prognostic markers in patients with early systemic sclerosis: a multicentre, prospective, observational study. PLoS One 2014; 9: e88150.

19. Chora I, Guiducci S, Manetti M, et al. Vascular biomarkers and correlation with peripheral vasculopathy in systemic sclerosis. Autoimmun Rev 2015; 14: 314-22.

20. Kuryliszyn-Moskal A, Klimiuk PA, Sierakowski S. Soluble adhesion molecules (sVCAM-1, sE-selectin), vascular endothelial growth factor (VEGF) and endothelin-1 in patients with systemic sclerosis: relationship to organ systemic involvement. Clin Rheumatol 2005; 24: 111-6.

21. Valim V, Assis LS, Simões MF, et al. Correlation between serum E-selectin levels and panoramic nailfold capillaroscopy in systemic sclerosis. Braz J Med Biol Res 2004; 37: 1423-7.

22. Lis-Święty A. Badanie stężenia rozpuszczalnego receptora interleukiny 2 w surowicy u chorych z objawem Raynauda i twardziną układową. Dermatol Klin 2007; 94: 563-9.
23. Ihn H, Sato S, Fujimoto M. Clinical significance of serum levels of soluble interleukin-2 receptor in patients with localized scleroderma. Br J Dermatol 1996; 134: 843-7.

24. Uziel Y, Krafchik BR, Feldman B, et al. Serum levels of soluble interleukin-2 receptor. A marker of disease activity in localized scleroderma. Arthritis Rheum 1994; 37: 898-901. 